Qin HE

Yabing ZHA

Ruijun ZHANG

Quan SUN

Tianyu LIU

\title{
RELIABILITY ANALYSIS FOR MULTI-STATE SYSTEM BASED ON TRIANGULAR FUZZY VARIETY SUBSET BAYESIAN NETWORKS
}

\section{ANALIZA NIEZAWODNOŚCI SYSTEMU WIELOSTANOWEGO Z ZASTOSOWANIEM SIECI BAYESOWSKICH OPARTYCH NA ROZMYTYCH PODZBIORACH ZMIENNOŚCI OPISANYCH PRZEZ TRÓJKĄTNĄ FUNKCJĘ PRZYNALEŻNOŚCI}

\begin{abstract}
In this paper, a novel reliability analysis method for multi-state system is proposed on the basis of triangular fuzzy variety subset Bayesian network (BN). The method considers fuzziness, multi-state, and variety of failure probability over time. With advantages in modeling and computation, the BN is utilized for reliability analysis. Fuzzy set theory is introduced into the BN analysis by using triangular fuzzy variety subset to describe failure probability. The uncertainty of fault logical relationship between different nodes is described through fuzzy conditional probability tables. As a function of time, the failure probability of each root node is analyzed first. Subsequently, the triangle fuzzy variety subset is established to describe the fuzzy failure probability of root nodes. This subset is applied to analyze the reliability of multi-state system fuzzy BN. Finally, a case study on the car free movement accident of flexible high-speed elevator lift system is used to demonstrate the effectiveness and practicality of the proposed method. Results show that the proposed approach could effectively address the problems on information uncertainty and multi-state in the early stage.
\end{abstract}

keywords: reliability analysis; fuzzy set theory; multi-state system; Bayesian network; elevator free movement accident.

\begin{abstract}
W niniejszej pracy zaproponowano nowa metodę analizy niezawodności systemów wielostanowych wykorzystująca sieci Bayesa (BN) oparte na rozmytych podzbiorach zmienności opisanych za pomoca trójkątnej funkcji przynależności. Metoda ta uwzględnia rozmyty charakter danych dotyczących uszkodzeń, wielostanowość systemu oraz zmienność prawdopodobieństwa wystapienia uszkodzenia w czasie. BN, które znalazły zastosowanie w modelowaniu i metodach obliczeniowych, wykorzystuje się także do analizy niezawodności. W przedstawionych badaniach, analize BN uzupetniono o elementy teorii zbiorów rozmytych wykorzystując do opisu prawdopodobieństwa wystapienia uszkodzenia, podzbiory zmienności opisane przez trójkątna funkcję przynależności. Niepewność zależności logicznej pomiędzy awariami reprezentowanymi przez różne węzły sieci opisano za pomoca tabel rozmytego prawdopodobieństwa warunkowego. W pierwszej kolejności analizowano prawdopodobieństwo uszkodzenia każdego korzenia (węzła głównego) w funkcji czasu. Następnie, wyznaczono trójkątny rozmyty podzbiór zmienności, za pomoca którego opisano rozmyte prawdopodobieństwo uszkodzenia węzłów głównych. Podzbiór ten wykorzystano do analizy niezawodności systemu wielostanowego przy pomocy rozmytych BN. Artykut kończy opis wypadku podczas ruchu wózka windy szybkobieżnej, który potwierdza skuteczność i możliwość praktycznego wykorzystania proponowanej metody. Wyniki pokazuja, że proponowane podejście może skutecznie rozwiazywać na wczesnym etapie problemy zwiazane z niepewnościa informacji oraz wielostanowościa systemu.
\end{abstract}

Stowa kluczowe: analiza niezawodności; teoria zbiorów rozmytych; system wielostanowy; sieć bayesowska; wypadek podczas ruchu wózka windy.

\section{Introduction}

Reliability is significant in describing the performance of a system. System reliability indicates the capability of a system to perform specified functions under definite conditions and within limited time period. System reliability analysis methods can help calculate the value of system reliability and determine the weakness of a system. Therefore, a system reliability analysis model, which is close to the actual system, should be established. This model will provide theoretical support for research, improvement, and maintenance.

In recent years, system reliability theory is rapidly developed. Numerous system reliability analysis methods, such as fault tree analysis methods [5], binary decision diagram (BDD) analysis methods [6, 9], T-S fuzzy fault tree analysis methods [16] and Bayesian networks
(BNs), are also emerging. Among the above methods, BN analysis methods $[10,2]$ are the most widely applied in system reliability analysis [17] and fault diagnosis [2] because of their advantages in both modeling capability and analysis process. The traditional BN reliability analysis methods are based on the hypothesis of two-state simple series-parallel systems $[1,3]$; these systems ignore the fuzziness of information and polymorphism of fault states in actual systems and consequently limit their application. In the past few years, further research used $\mathrm{BN}$ analysis methods to overcome the aforementioned problems. In [12], BNs were introduced to dynamic system reliability evaluation; moreover, traditional $\mathrm{BN}$ reliability analysis methods were further developed to improve the efficiency and accuracy of calculation and extend the application scope. BNs were combined with fuzzy set theory to predict the safety risk of subway operation and analyze 
the most important risk factor affecting fire accidents [11]. A reliability analysis model for fuzzy multi-state systems was established in [4] by introducing fuzzy set theory into BN modeling; the resulting model was applied on hydraulic systems. However, these system reliability research methods are mostly based on the assumption of static failure information, and "change" is a basic characteristic of an actual system. Therefore, a system reliability model, which considers changing failure probabilities, should be established.

In [15], a system reliability model was established by using loadstrength interference model, order statistics, and Poisson stochastic process. This model was applied on series, parallel, and $\mathrm{k} / \mathrm{n}$ systems. The evolution characteristics of system reliability and failure probability over time were also studied. Considering the effects of strength degradation on system reliability, a reliability model as a function of load frequency and time was proposed in [13]; such model can be applicable on series-parallel systems. These methods are based on the assumption that all components are identical, and the working loads are not changed. Thus, they can only analyze simple series-parallel system under a relatively stable working environment. In complex mechanical systems, these methods cannot reflect the actual situation, thereby limiting their promotion and application. Fuzziness, polymorphism, and variability are the three basic characteristics of complex mechanical systems. Ignoring any one of them may lead to significant errors and wrong conclusions in system reliability analysis. Therefore, a further complete BN models considering the fuzziness, multistate, and dynamics in failure information have attracted considerable attention, specifically in system reliability analysis.

In this paper, fuzzy set theory is introduced into $\mathrm{BN}$ analysis. The multi-state variety system reliability analysis methods, which consider the system component's failure probability variation with time, are also studied. Finally, this new method is applied in the car elevator free accident of high-speed elevator flexible lifting system.

The remaining part of the paper is organized as follows. In Section 1, the BN methods are introduced. In Section 2, system reliability analysis methods based on triangular fuzzy BN are proposed. In Section 3, the car elevator free accident of high-speed elevator flexible lifting system is analyzed by using the proposed method. In Section 4 , the conclusions and some suggestions for further studies are provided.

\section{BNs}

BNs, which are also known as belief networks, probabilistic networks, and causal diagrams, are a kind of uncertainty representation and reasoning models based on probabilistic analysis and graph theory $[7,14]$.

BNs consist of one directed acyclic graph and some conditional probability tables, which are used to describe the probabilistic dependencies of variables. A BN can be denoted as $N=((X, T), P)$, where $(X, T)$ is the directed acyclic graph with $N$ nodes, and $P$ indicates the conditional probability table of each node. $X=\left(x_{1}, x_{2}, \cdots, x_{n}\right)$ is the set of all node variables. Node variable can be the abstract of any specific question, such as component status, observational information, or personnel operation. $T$ represents the directed edges between two variables, which are used to describe the relationship between two variables. The directed edges indicate links to be directed from parent nodes to child nodes. The nodes without a parent node are root nodes, and those without a child node are leaf nodes. The conditional probability table $P$ is used to describe logical relationships. According to the conditional independence assumption of BNs, the conditional probability distribution can be represented by $P\left(X_{i} \mid \pi\left(X_{i}\right)\right)$, where $\pi\left(X_{i}\right)$ indicates the set of parent nodes of $X_{i}$.
$\mathrm{BN}$ can be used to conduct either qualitative analysis or quantitative analysis. The directed acyclic graph is utilized to conduct the qualitative analysis by describing the relationship between two variables. Quantitative analysis is performed using the conditional probability table that can describe the correlation between a node and its parent nodes. When the priori probability and conditional probability tables of root nodes are known, the joint probability distribution can be described as follows:

$$
P\left(X_{1}, X_{2}, \cdots, X_{n}\right)=\prod_{i=1}^{n} P\left(X_{i} \mid \pi\left(X_{i}\right)\right)
$$

\section{Reliability analysis of a triangle fuzzy variety $B N$ system}

Fuzzy BN considers fuzziness and variation in the component failure information of a multi-state system. The triangle fuzzy variety subset is constructed to describe the BN root nodes. The fuzzy BN nodes are introduced into the $\mathrm{BN}$ model to calculate the multi-state system fuzzy reliability and fuzzy importance of root nodes with BN inference algorithms. Furthermore, the goal of multi-state system reliability analysis is realized.

\subsection{Triangular fuzzy variety subset construction}

In the traditional BN-based reliability analysis methods, the failure probability of a node is usually assumed as the average value of this type of component. Nevertheless, the failure probability of most components is fuzzy and varies with time in actual condition. In this paper, we use a triangular fuzzy subset to describe the root nodes.

First, we obtained the relationship between failure probability and time by analyzing the failure data of components in a system. Given that the obtained failure data are discrete, modeling of time-varying failure probability accurately through simple functions is difficult. Therefore, the failure probability is fuzzy. For example, the failure probability variation of a transmission in its initial stage is depicted in Fig. 1 [18], where "experiment 1" and "experiment 2" are the failure probability curves of two experiments. Results show that failure probability increases irregularly over time between two lines, namely, the upper and lower limit lines. A simple function cannot be easily used to describe the relationship between failure probability and time. The failure probability of most mechanical components in the initial stage is similar to that of the rope spring in Fig. 1.

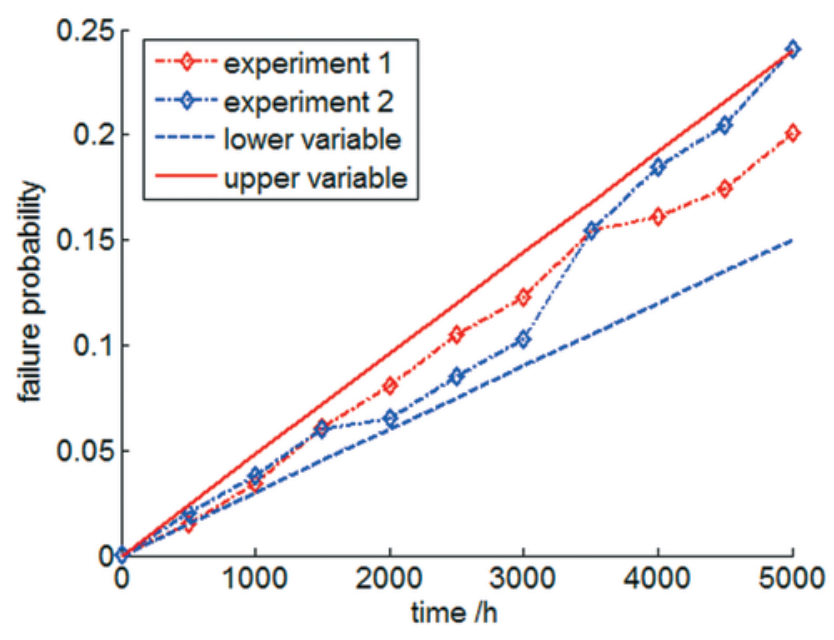

Fig. 1. Failure probability variation of rope spring in its initial stage 
We use the fuzzy subset to replace the fixed value and describe failure probability of a component at a specified time $t$. Many kinds of membership function, such as triangular, trapezoidal, normal, and lognormal membership functions, are used to describe fuzzy subset. With the advantage of simple algebraic operation, triangular membership function is most widely used and thereby adopted in this study. In addition to variation range, triangular membership function can also highlight the most possible value of a fuzzy variable.

$\tilde{P}_{i j}(t)$ is the probability that the fault state of node $x_{i}$ is $x_{i}^{j}$ at time $t$. Consequently, the triangular fuzzy subset of $\tilde{P}_{i j}(t)$ can be denoted as $\left(h_{i j}^{l}(t), h_{i j}^{m}(t), h_{i j}^{r}(t)\right)$ :

$$
\left\{\begin{array}{c}
h_{i j}^{l}(t)=a_{i j}^{l} t+b_{i j}^{l} \\
h_{i j}^{m}(t)=a_{i j}^{m} t+b_{i j}^{m} \\
h_{i j}^{r}(t)=a_{i j}^{r} t+b_{i j}^{r}
\end{array}\right.
$$

where $a_{i j}^{l}, a_{i j}^{m}, a_{i j}^{r}, b_{i j}^{l}, b_{i j}^{m}, b_{i j}^{r}$ are all constants, $\left\{b_{i j}^{l}, b_{i j}^{m}, b_{i j}^{r}\right\}$ represents the triangular fuzzy variety subset at the initial time $t=0, h_{i j}^{m}(t)$ is the center-variable function of fuzzy variety subset at time $t$, and $h_{i j}^{m}(t)-h_{i j}^{l}(t)$ and $h_{i j}^{r}(t)-h_{i j}^{m}(t)$ are the left and right fuzzy areas, respectively. The uncertainty of variable increases with increasing

fuzzy area. The membership function of $\tilde{P}_{i j}(t)$ is defined by Eq. (3), which is also shown in Fig. 1.

$$
\mu_{\tilde{p}_{i j}(h)}=\left\{\begin{array}{ll}
\max \left(0,1-\frac{h_{i j}^{m}(t)-h}{h_{i j}^{m}(t)-h_{i j}^{l}(t)}\right) & 0 \leq h \leq h_{i j}^{m}(t) \\
\max \left(0,1-\frac{h-h_{i j}^{m}(t)}{h_{i j}^{r}(t)-h_{i j}^{m}(t)}\right) & h_{i j}^{m}(t) \leq h \leq 1
\end{array}\right\},
$$

where $h$ indicates the failure probability at time $t$.

The time-varying property of a root node's failure probability is also considered. A series of triangular fuzzy subset can be calculated to describe the variation of a root node's failure probability over time, which is shown in Fig. 3.

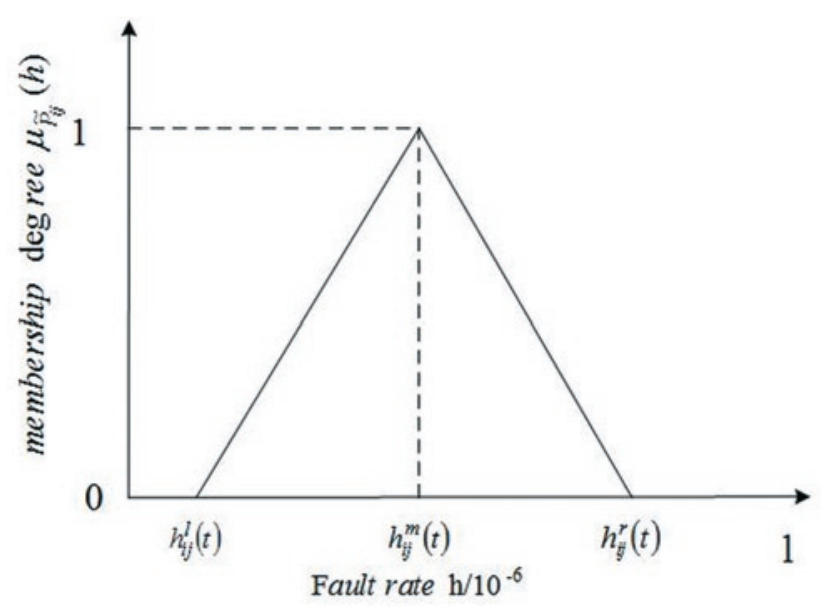

Fig. 2. Membership function of $\tilde{P}_{i j}(t)$

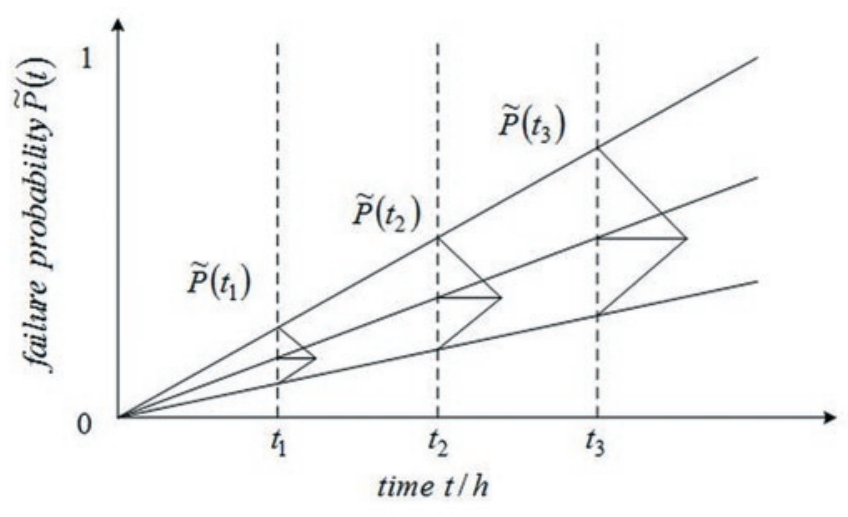

Fig. 3. Failure probability of a node varies over time

\subsection{Failure possibility of a fuzzy BN system}

Root nodes are used to represent all the basic events in the BN system, which are denoted as $x_{i}(i=1,2, \cdots, n) . T$ is the leaf node that describes the failure state of the system. The other events of the $\mathrm{BN}$ system are represented by the middle nodes, which are denoted as $y_{k}(k=1,2, \cdots, m)$. The fuzzy numbers $x_{i}^{j}, y_{k}^{v}, T_{v}$ are used to describe the fault states of the three types of nodes. $\tilde{P}_{T=T_{v}}(t)$ denotes the fuzzy probability that leaf node $T$ is in fault state $T_{v}$, which can be expressed as a function of $\tilde{P}_{i j}(t)$ :

$$
\begin{aligned}
\tilde{P}_{T=T_{v}}(t)= & \sum_{x_{1}, \cdots x_{n}, y_{1} \cdots y_{m}} \tilde{P}\left(x_{1}, \cdots x_{n}, y_{1} \cdots y_{m}, T_{v}\right)= \\
& \sum_{\pi(T)} \tilde{P}\left(T=T_{v} \mid \pi(T)\right) \sum_{\pi\left(y_{1}\right)} \tilde{P}\left(y_{1} \mid \pi\left(y_{1}\right)\right), \\
& \times \cdots \times \tilde{P}_{1}(t) \cdots \tilde{P}_{n}(t)
\end{aligned}
$$

where $\pi(T)$ is the set of all parent nodes of leaf node $T$, and $\pi\left(y_{1}\right)$ is the set of all parent nodes of the middle node $y_{1}$.

\subsection{Importance of a fuzzy BN system}

In a multi-state system, the fuzzy $\mathrm{BN}$ reflects the comprehensive evaluation of a root node under different fault states. $\tilde{p}_{i j}(t)$ refers to the fuzzy subset of the failure probability that node $x_{i}$ is in fault state $x_{i}^{j}$ at time t, and $u_{\tilde{P}_{i j}}(t)$ is the corresponding membership function. Thus, the fuzzy importance of root node in fault state $x_{i}^{j}$ with leaf node $T$ in fault state $T_{q}$ is as follows:

$$
\begin{gathered}
I_{i j}^{F_{u}}(t)=E\left[\tilde{P}\left(T=T_{q} \mid x_{i}=x_{i}^{j}\right)-\tilde{P}\left(T=T_{q} \mid x_{i}=0\right)\right] \\
=\frac{\int_{0}^{1} x \mu_{\tilde{P}^{i j, T_{q}}}(t) d x}{\int_{0}^{1} \mu_{\tilde{P}^{i j, T_{q}}}(t) d x}-\frac{\int_{0}^{1} x \mu_{\tilde{P}_{i j, 0}}(t) d x}{\int_{0}^{1} \mu_{\tilde{P}_{i j, 0}}(t) d x},
\end{gathered}
$$

where $\tilde{P}\left(T=T_{v} \mid x_{i}=x_{i}^{j}\right)$ is the fuzzy probability that leaf node is in fault state $T_{v}$ and conditional on that the root node $x_{i}$ is in fault state $x_{i}^{j}$. The two integral terms are gravity values of $\tilde{P}\left(T=T_{v} \mid x_{i}=x_{i}^{j}\right)$ and $\tilde{P}\left(T=T_{v} \mid x_{i}=0\right)$. 
The fuzzy importance of root node $x_{i}$ with leaf node $T$ at fault state $T_{q}$ is as follows:

$$
I_{i}^{F_{u}}(t)=\frac{\sum_{j=1}^{m} I_{i j}^{F_{u}}(t)}{m},
$$

where $m$ is the number of fault states for root node $x_{i}$, and $I_{i}^{F_{u}}(t)$ is the average importance of fault state $x_{i}^{j}$ at time $\mathrm{t}$ when its fault state changes from 0 to 1 .

Equations (4) to (6) show that the proposed reliability analysis method can realize reliability estimation for multi-state systems through optimizing the fuzzy and time-varying fault information. Moreover, the method can help engineers perform fault diagnosis for a system with the results of importance analysis.

\section{Case study}

The flexible lifting system is the core mechanical part of an elevator [19]. The system consists of three parts: safety protection, traction, and track subsystems. The safety protection subsystem mainly includes safety clamp, rope clip, and buffer. The track subsystem mainly includes rails, guide wheels, car frame, and guide shoe. The traction subsystem mainly includes traction rope, traction wheels, and traction machine. During operation, component damage often causes slip ladder accident, which will seriously affect the safety of passengers. Thus, the reliability of the flexible lifting system in high-speed elevators should be dynamically analyzed. The most important component

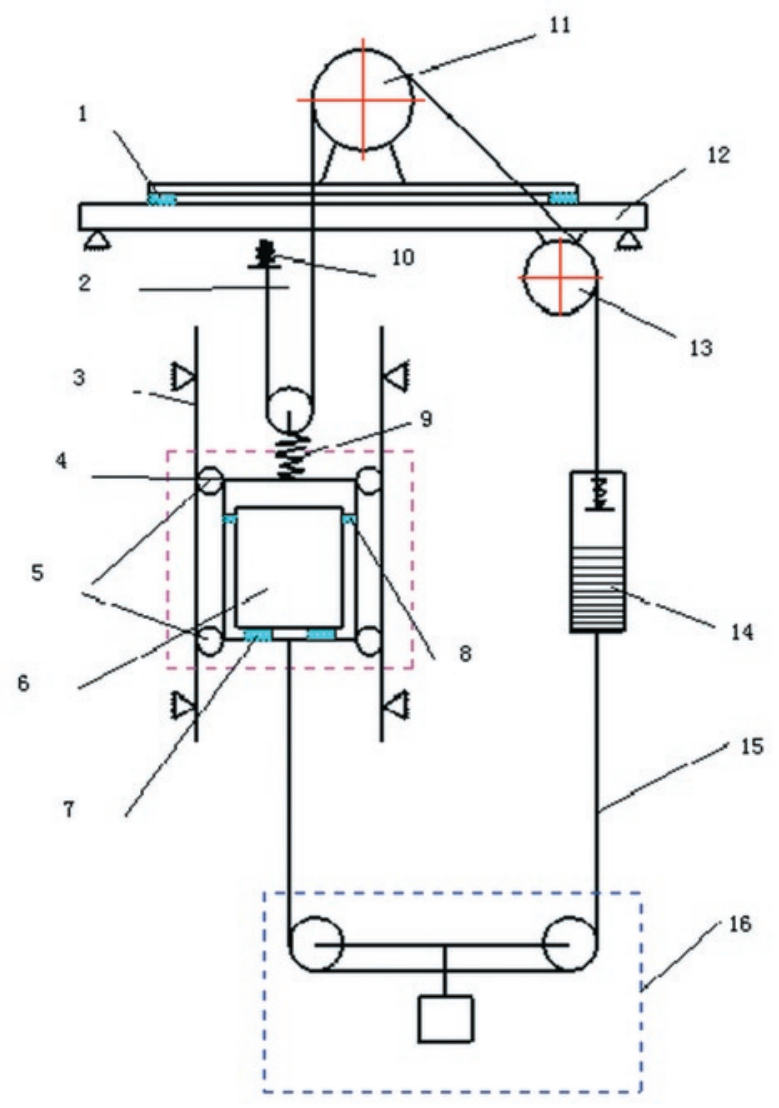

1. base rubber, 2. traction rope, 3. rail, 4. guide wheel, 5. car frame, 6. car, 7. bottom rubber of car, 8. damping rubber, 8. top rubber of car, 10. spring of rope end, 11. traction wheel, 12. bearing beam, 13. steering wheel, 14. counterweight, 15. compensation rope, 16. tensioning system

Fig. 4. Flexible lifting system of a high-speed elevator

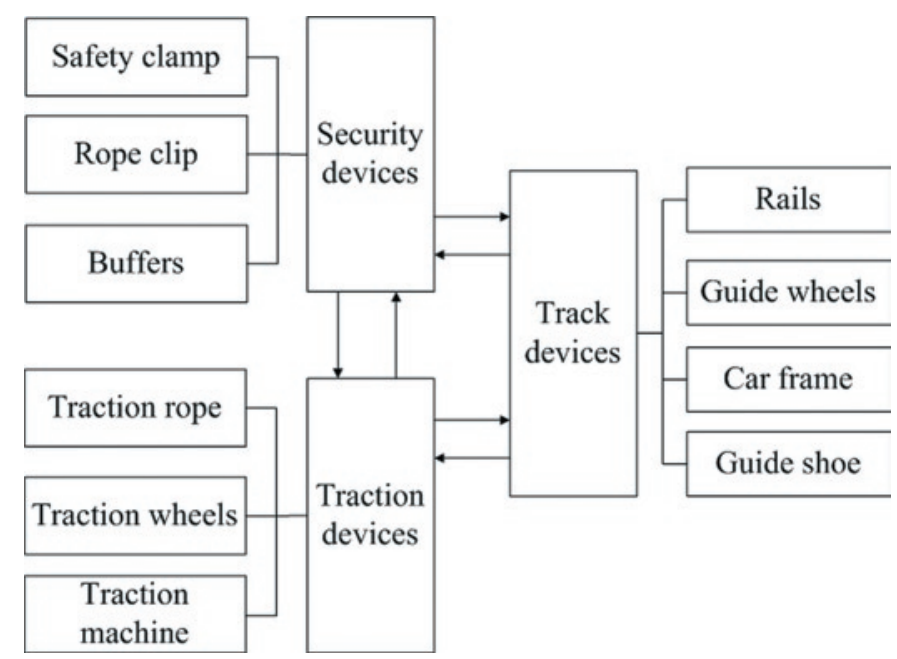

Fig. 5. Car slipping accident of flexible lifting system

seriously affecting car slipping accident should also be determined. As an example, the schematic diagram of one type of high-speed elevator is depicted in Fig. 4. Figure 5 shows the main components, which can cause elevator car slipping accident, and the interaction relationships among them.

BN was used to describe the working states of the elevator's flexible lifting system. The leaf node $T$ is the slipping accident of the elevator car. $x_{1} \sim x_{10}$ are root nodes, which represent the safety clamp, rope clip, buffer, rails, guide wheels, safety gear, guide shoe, traction rope, traction wheels, and traction machine, respectively. $y_{1} \sim y_{3}$ are the middle nodes, which represent the safety, traction, and track devices, respectively. The BN model of car slipping accident $T$ in the flexible lifting system of a high-speed elevator is shown in Fig. 6.

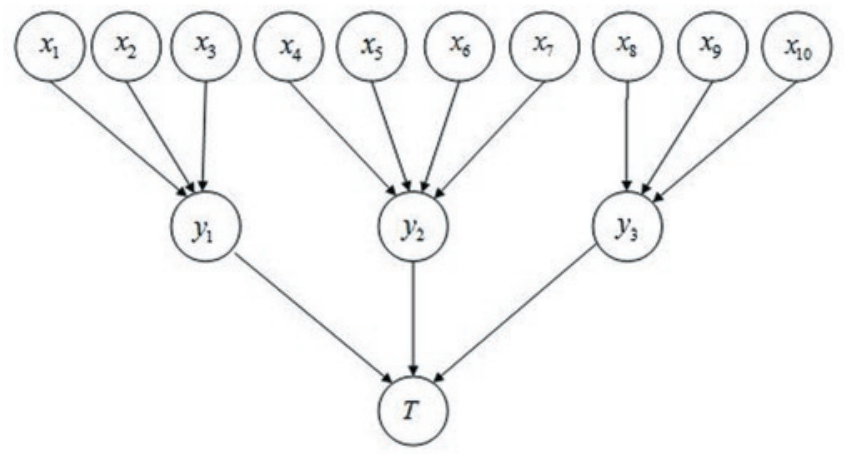

Fig. 6. Bayesian network model of car slipping accident in the flexible lifting system of a high-speed elevator.

The set of all fault states of nodes $x_{1} \sim x_{10}, y_{1} \sim y_{3}$, and $T$ is ( 0 , $0.5,1)$, i.e., $x_{i}^{1}=0, x_{i}^{2}=0.5$, and $x_{i}^{3}=1$, respectively During reliability analysis, the fuzziness and uncertainty of fault logic relationships among different components are considered. According to historical data and expert information, the CPT of middle nodes $y_{1} \sim y_{3}$ and leaf node $T$ is obtained; results are shown in Tables $1-4$, respectively [19]. The conditional probability of each child node can be obtained under the combinations of parent nodes in all fault states.

\subsection{Fault probability analysis}

Given that the component performance and working environments of different elevators are different, the tendencies of components' failure probability with time also vary. Experimental data 
Table 1. The CPT of node $y_{1}$.

\begin{tabular}{|c|c|c|c|c|c||}
\hline$x_{1}$ & $x_{2}$ & $x_{3}$ & $P\left(y_{1}=0 \mid x_{1} \sim x_{3}\right)$ & $P\left(y_{1}=0.5 \mid x_{1} \sim x_{3}\right)$ & $P\left(y_{1}=1 \mid x_{1} \sim x_{3}\right)$ \\
\hline 0 & 0 & 0 & 1 & 0 & 0 \\
\hline 0 & 0 & 0.5 & 0.1 & 0.5 & 0.4 \\
\hline 0 & 0 & 1 & 0 & 0.3 & 0.7 \\
\hline$\ldots$ & $\ldots$ & $\ldots$ & $\ldots$ & $\ldots$ & $\ldots$ \\
\hline 1 & 1 & 0 & 0 & 0 & 1 \\
\hline 1 & 1 & 0.5 & 0 & 0 & 1 \\
\hline 1 & 1 & 1 & 0 & & 0 \\
\hline
\end{tabular}

Table 2. The CPT of node $y_{2}$.

\begin{tabular}{|c|c|c|c|c|c|c||}
\hline$x_{4}$ & $x_{5}$ & $x_{6}$ & $x_{7}$ & $P\left(y_{2}=0 \mid x_{4} \sim x_{7}\right)$ & $P\left(y_{2}=0.5 \mid x_{4} \sim x_{7}\right)$ & $P\left(y_{2}=1 \mid x_{4} \sim x_{7}\right)$ \\
\hline 0 & 0 & 0 & 0 & 1 & 0 & 0 \\
\hline 0 & 0 & 0 & 0.5 & 0.4 & 0.3 & 0.3 \\
\hline 0 & 0 & 0 & 1 & 0.2 & 0.3 & 0.5 \\
\hline$\ldots$ & $\ldots$ & $\ldots$ & $\ldots$ & $\ldots$ & 0 & 1 \\
\hline 1 & 1 & 1 & 0 & 0 & 0 & 1 \\
\hline 1 & 1 & 1 & 0.5 & 0 & 0 & 1 \\
\hline 1 & 1 & 1 & 1 & 0 & 0 & 0 \\
\hline
\end{tabular}

Table 3. The CPT of node $y_{3}$.

\begin{tabular}{|c|c|c|c|c|c||}
\hline$x_{8}$ & $x_{9}$ & $x_{10}$ & $P\left(y_{3}=0 \mid x_{8} \sim x_{10}\right)$ & $P\left(y_{3}=0.5 \mid x_{8} \sim x_{10}\right)$ & $P\left(y_{3}=1 \mid x_{8} \sim x_{10}\right)$ \\
\hline 0 & 0 & 0 & 1 & 0 & 0 \\
\hline 0 & 0 & 0.5 & 0.3 & 0.4 & 0.3 \\
\hline 0 & 0 & 1 & 0 & 0.4 & 0.6 \\
\hline$\ldots$ & $\ldots$ & $\ldots$ & $\ldots$ & $\ldots$ & 1 \\
\hline 1 & 1 & 0 & 0 & 0 & 1 \\
\hline 1 & 1 & 0.5 & 0 & 0 & 1 \\
\hline 1 & 1 & 1 & 0 & 0 & $\ldots$ \\
\hline
\end{tabular}

Table 4. The CPT of node $T$.

\begin{tabular}{|c|c|c|c|c|c||}
\hline$y_{1}$ & $y_{2}$ & $y_{3}$ & $P\left(T=0 \mid y_{1} \sim y_{3}\right)$ & $P\left(T=0.5 \mid y_{1} \sim y_{3}\right)$ & $P\left(T=1 \mid y_{1} \sim y_{3}\right)$ \\
\hline 0 & 0 & 0 & 1 & 0 & 0 \\
\hline 0 & 0 & 0.5 & 0.3 & 0.5 & 0.2 \\
\hline 0 & 0 & 1 & 0.1 & 0.2 & 0.7 \\
\hline$\ldots$ & $\ldots$ & $\ldots$ & $\ldots$ & $\ldots$ & $\ldots$ \\
\hline 1 & 1 & 0 & 0 & 0 & 1 \\
\hline 1 & 1 & 0.5 & 0 & 0 & 1 \\
\hline 1 & 1 & 1 & 0 & 0 & 1 \\
\hline
\end{tabular}

analysis showed that the failure probability triangular fuzzy subset of each node at fault state 1 is summarized in Table 5.

The fuzzy variety subset of node $x_{1}-x_{10}$ at fault state 0.5 is the same as the subset at fault state 1. According to Eqs. 2 to 4 and Tables 1 to 4 , the fuzzy failure probability of the system at different fault states are as follows: 
Table 5. Triangular dynamic fuzzy subset of root nodes at fault state 1.

\begin{tabular}{|c|c|}
\hline Root node $x_{i}$ & Fuzzy variety subset of root node $x_{i}$ at fault state $1 . \times\left(10^{-6} / h\right)$ \\
\hline$x_{1}$ & $\{12.5+15 \mathrm{t}, 13.5+16 \mathrm{t}, 14.5+17 \mathrm{t}\}$ \\
\hline$x_{2}$ & $\{0.11+0.2 \mathrm{t}, 0.25+0.3 \mathrm{t}, 0.39+0.4 \mathrm{t}\}$ \\
\hline$x_{3}$ & $\{11.1+12 \mathrm{t}, 25+24 \mathrm{t}, 38.9+42 \mathrm{t}\}$ \\
\hline$x_{4}$ & $\{15+10 \mathrm{t}, 20+20 \mathrm{t}, 25+30 \mathrm{t}\}$ \\
\hline$x_{5}$ & $\{0.7+0.5 \mathrm{t}, 1.5+1.5 \mathrm{t}, 2.3+2.5 \mathrm{t}\}$ \\
\hline$x_{6}$ & $\{0.021+0.02 \mathrm{t}, 0.047+0.05 \mathrm{t}, 0.073+0.08 \mathrm{t}\}$ \\
\hline$x_{7}$ & $\{2.4+2.5 \mathrm{t}, 5.5+5.5 \mathrm{t}, 8.6+8.5 \mathrm{t}\}$ \\
\hline$x_{8}$ & $\{0.004+0.002 \mathrm{t}, 0.008+0.004 \mathrm{t}, 0.012+0.008 \mathrm{t}\}$ \\
\hline$x_{9}$ & $\{0.25+0.2 \mathrm{t}, 0.26+0.3 \mathrm{t}, 0.27+0.4 \mathrm{t}\}$ \\
\hline$x_{10}$ & $\{3.2+3 \mathrm{t}, 4.2+4 \mathrm{t}, 5.2+5 \mathrm{t}\}$ \\
\hline
\end{tabular}

$$
\begin{aligned}
\tilde{P}_{T=1}(t)= & \sum_{x_{1}, \cdots, x_{10}, y_{1}, \cdots, y_{3}} \tilde{P}\left(x_{1}, \cdots, x_{10}, y_{1}, y_{2}, y_{3}, T=1\right) \\
= & \sum_{y_{1}, y_{2}, y_{3}} \tilde{P}\left(T=1 \mid y_{1}, y_{2}, y_{3}\right) \times \sum_{x_{1}, x_{2}, x_{3}} \tilde{P}\left(y_{1} \mid x_{1}, x_{2}, x_{3}\right) \\
& \times \tilde{P}_{1}(t) \tilde{P}_{2}(t) \tilde{P}_{3}(t) \times \sum_{x_{4}, \cdots, x_{7}} \tilde{P}\left(y_{2} \mid x_{4}, \cdots, x_{7}\right) \\
& \times \tilde{P}_{4}(t) \cdots \tilde{P}_{7}(t) \times \sum_{x_{8}, x_{9}, x_{10}} \tilde{P}\left(y_{3} \mid x_{8}, x_{9}, x_{10}\right) \\
& \times \tilde{P}_{8}(t) \tilde{P}_{9}(t) \tilde{P}_{10}(t)
\end{aligned}
$$

Figures 7 and 8 show the analysis results of dynamic reliability analysis method based on fuzzy BNs and the fault tree analysis method [8].

The failure probability result of the proposed method is a triangular fuzzy variety subset that includes the upper limit, center variable, and lower limit. In the traditional fault tree analysis method, the failure probability is only a curve because of ingoing information uncertainty. When the system possesses sufficient information data, and the

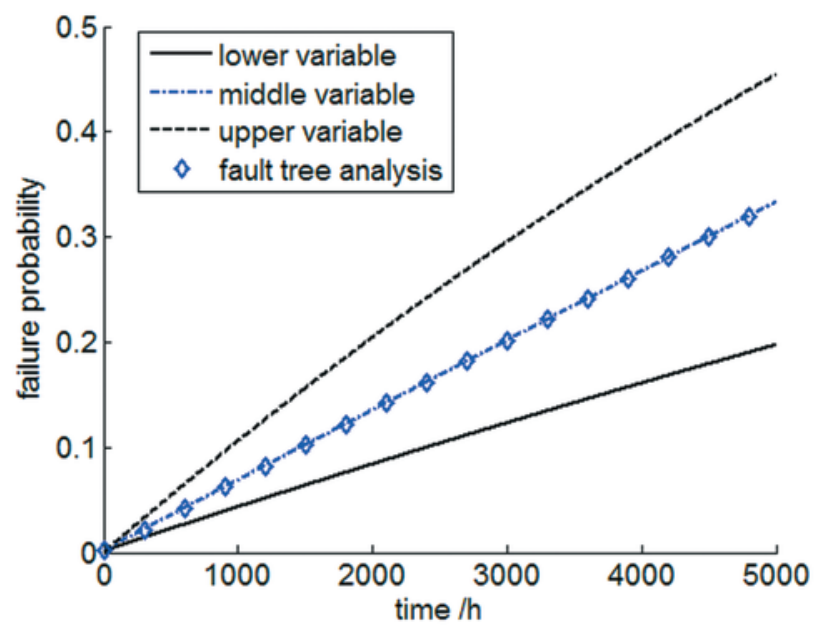

Fig. 7. Result comparison of leaf $T$ node at fault state 1.

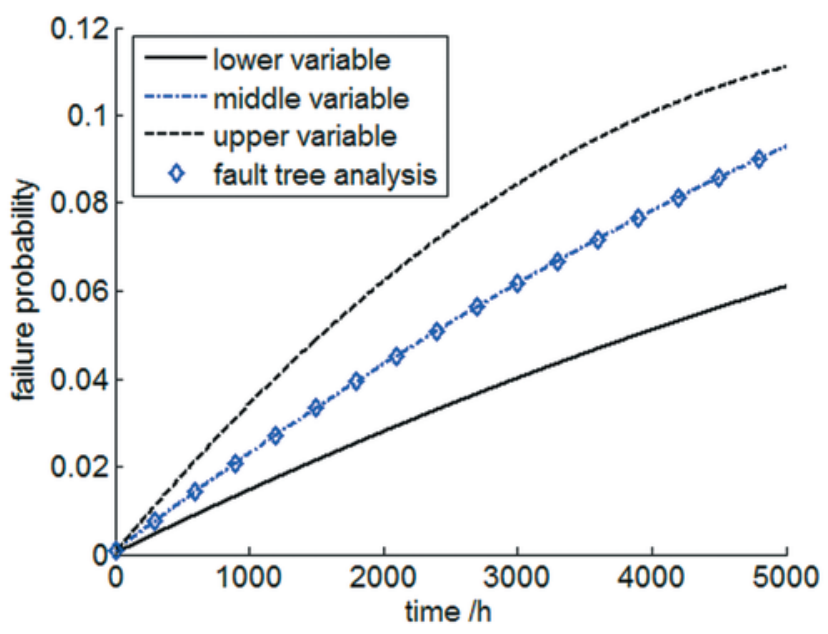

Fig. 8. Result comparison of leaf T node at fault state 0.5.

fault logic relationship is clear, then the fault tree analysis method is the most suitable option because of its simple calculation. However, when the fault logic relationship is uncertain, and insufficient fault information is available, then the proposed method is suitable for reliability analysis.

\subsection{Importance analysis}

Equation 5 shows that the fuzzy importance of root node $x_{1}$ at fault state 1 with leaf node $T$ at fault state 1 is as follows:

$$
\begin{aligned}
I_{11}^{F_{u}}(t) & =E\left[\tilde{P}\left(T=1 \mid x_{1}=1\right)-\tilde{P}\left(T=1 \mid x_{1}=0\right)\right] \\
& =\frac{\int_{0}^{1} x \mu_{\tilde{P}_{11,1}}(t) d x}{\int_{0}^{1} \mu_{\tilde{P} 11,1}(t) d x}-\frac{\int_{0}^{1} x \mu_{\tilde{P}_{11,0}}(t) d x}{\int_{0}^{1} \mu_{\tilde{P}_{11,0}}(t) d x}
\end{aligned}
$$

Similarly, the fuzzy importance of root node $x_{1}$ at fault state 0.5 with leaf node $T$ at fault state 1 can be obtained. Equation 6 illustrates 
that the fuzzy importance of root node $x_{1}$ with leaf node $T$ at fault state 1 is as follows;

$$
I_{1}^{F_{u}}(t)=\frac{\sum_{j=1}^{2} I_{1 j}^{F_{u}}(t)}{2}
$$

Figure 9 shows the importance results of root node $x_{1}$ using the proposed methods. With the above calculation methods, the fuzzy importance of other root nodes can also be obtained.

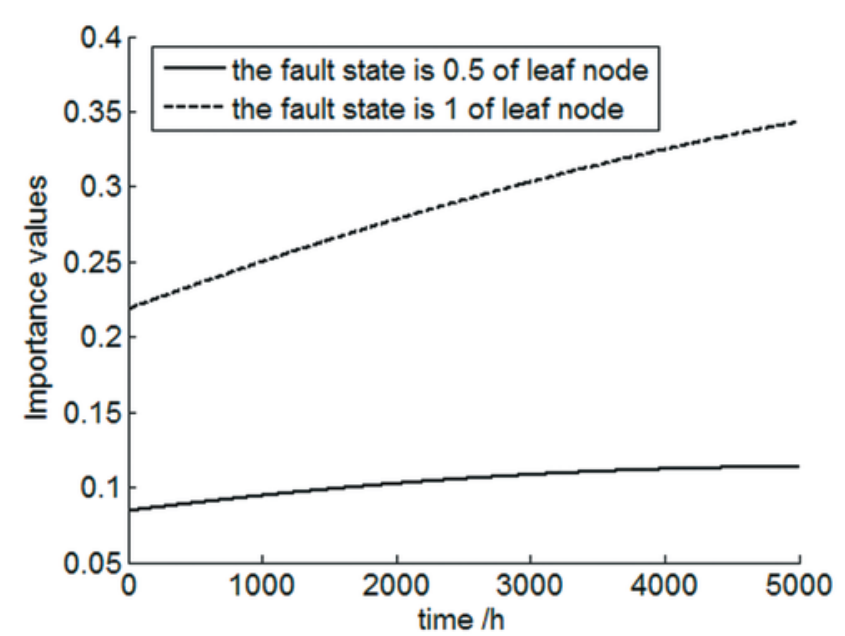

Fig. 9. Dynamic fuzzy importance of root node $x_{1}$ when leaf node $T$ at fault states 0.5 and 1

The traditional T-S fuzzy importance based on failure probability and fuzzy subset is a time-independent value. By contrast, the BN fuzzy importance considers the various information of a system and thus can derive a time-dependent curve. Figure 9 shows that the im- portance of root node $x_{1}$ when the leaf node $T$ is at fault state 0.5 is a curve with little variation over time, which is close to a constant value. Thus, the T-S fuzzy importance analysis method can be used for an approximate calculation. The fuzzy importance of root node $x_{1}$ when the leaf node $T$ is at fault state 1 is a curve, which changes drastically over time; hence, it cannot be calculated using the traditional T-S fuzzy importance methods.

This study fully considered fuzziness and variety of failure information in an actual system. This method can completely utilize faulty information compared with the traditional system reliability analysis methods. Additionally, the results match relatively well with the actual situations. However, some subjective information, such as expert information, is needed in this method. Consequently, the objectivity of analysis results is influenced to some extent.

\section{Conclusion}

In this study, triangular fuzzy variety subset is used to describe the failure probability of components that vary with time. The proposed method considers the variety, fuzziness, and uncertainty of component failure probability and can achieve an accurate reliability analysis result. The fuzzy multi-state CPT is used to describe the failure mechanism between two different components. Many actual objective factors are considered in this method compared with the traditional fault tree analysis method. Finally, a case study on the car slipping accident of a flexible lifting system is conducted to demonstrate the effectiveness of the proposed method. However, the proposed method is limited by that it can only deal with initial failures of a system. In future work, the entire life cycle of system reliability will be investigated.

\section{Acknowledgements}

This work is supported by the National Natural Science Foundation of China under Grant 51075244 and the program of domestic study for young scholar of university of Shandong province.

\section{References}

1. Andrews JD, Beeson S, Birnbaum S. Measure of Importance for Non-coherent Systems. IEEE Trans Reliability 2003; 52: 213-219, https:// doi.org/10.1109/TR.2003.809656.

2. Borgonovo E. Differential, Criticality and Birnbaum Importance Measures: an Application to Basic Event, Groups and SSCs in Event Trees and Binary Decision Diagrams. Reliability Engineering and System Safety 2007; 92: 1458-1467, https://doi.org/10.1016/j.ress.2006.09.023.

3. Boudali H, Dugan JB. A Discrete-time Bayesian Network Reliability Modeling and Analysis Framework. Reliability Engineering and System Safety 2005; 87: 337-349, https://doi.org/10.1016/j.ress.2004.06.004.

4. Chen DN, Yao CY. Reliability Analysis of Multi-state System based on Fuzzy Bayesian Networks and Application in Hydraulic System. Journal of Mechanical Engineering 2012; 48: 175-183, https://doi.org/10.3901/JME.2012.16.175.

5. Du L, Gao JM, Chen K. Reliability Deployment based on Fault Correlation Analysis. Computer Integrated Manufacturing Systems 2011; 17: 1973-1980.

6. He M, Quan JC, Zheng X, et al. Network reliability evaluation based on binary decision diagrams. Control and Decision 2011; 26: 32-36.

7. Jensen F V. An Introduction to Bayesian Networks. New York: Springer Press; 1996.

8. Jin X, Hong YJ, Du HM. Reliability Analysis Method of Common Cause Failure System. Beijing: National Defense Industry Press; 2008.

9. Kuo S, Lu S, Yeh F. Determining teminal-pair reliability based on edge expansion diagrams using OBDD. IEEE. Trans Reliability 1999; 48: 234-246, https://doi.org/10.1109/24.799845.

10. Lin C T, Hong W C, Chen Y F, et al. Application of salesman-like recommendation system in $3 \mathrm{G}$ mobile phone online shopping decision support. Expert Systems with Applications 2010; 37: 8065-8078, https://doi.org/10.1016/j.eswa.2010.05.081.

11. Lu Y, Li QM, Zhou ZP. Safety Risk Prediction of Subway Operation based on Fuzzy Bayesian Network. Journal of Southeast University 2010; 40: 1110-1114.

12. Ma DZ, Zhou Z, Yu XY, et al. Reliability analysis of multi-state Bayesian networks based on fuzzy probability. Systems Engineering and Electronic 2012; 34: 2607-2611.

13. Matsuoka T, Kobayashi M. The GO-FLOW reliability analysis methodology-analysis of common cause failure with uncertainty. Nuclear Engineering and Design 1997; 175: 205-214, https://doi.org/10.1016/S0029-5493(97)00038-1.

14. Palaniappan RK. Bayesian networks: Application in safety instrumentation and risk reduction, ISA Transactions 2007; 46: 255-259, https:// doi.org/10.1016/j.isatra.2006.11.003. 
15. Son HS, Seong PH. A safety analysis method using fuzzy Petri nets. Annual Meeting of the North American Fuzzy Information Processing Society. Syracuse, New York: IEEE Press; 1997.

16. Yao CY, Zhang YY, Wang XF, et al. Importance analysis method of fuzzy fault tree based on T-S model. China Mechanical Engineering 2011; 22: 1261-1268.

17. Yin XW, Qian XW, Xie LY. Application of Bayesian Network to Reliability Assessment of Mechanical Systems. Journal of Northeastern University (Natural Science) 2008; 29: 557-560.

18. Zeng QH. Fault Prognostic Technologies Research for Key Parts and Components of Mechanical Transmission Systems. PhD dissertation. National University of Defense Technology, China; 2010.

19. Zhang Ruijun. Robust and optimization design with safety assessment technique of the parameter uncertainty. PhD dissertation. Beijng University of Posts and Telecommunication, China, 2015.

\section{Qin HE}

College of information System and Management national university of Defense Technology Sanyi Avenue, Changsha, China

School of Mechanical and Electrical Engineering, Shandong Jianzhu University, 250000, Fengming Road, Ji'nan, China

\section{Yabing ZHA}

College of Information System and Management, National University of Defense Technology,

410073, Sanyi Avenue, Changsha, China

\section{Ruijun ZHANG}

School of Mechanical and Electrical Engineering, Shandong Jianzhu University, 250000, Fengming Road, Ji'nan, China

\section{Tianyu LIU}

Troop 78092 of PLA

610036, No.14 Jinxianqiao Road, Chengdu, China

\section{Quan SUN}

College of Information System and Management, National University of Defense Technology, 410073, Sanyi Avenue, Changsha, China

E-mails: heqin67271@163.com, ybzha@nudt.edu.cn, zhangruijun@sdjzu.edu.cn, sunquan@nudt.edu.cn, liutianyu@nudt.edu.cn 